\title{
Chiral Phosphinooxazolidine Ligand Derived from Prolinol: Application to the Pd-Catalyzed Asymmetric Allylic Alkylation
}

\author{
Mỵug-Jong Jin, 'Sang-Joon Lee, and Young-Mok Kim \\ School of ('hemical, reience di Engineening, Inha Thiversity, Inchon 402-751, Korea \\ Received July 15,2002
}

Key Words : Asymmetric caltaly sis, Allylic alky lation. Phosphinooxadolidine. Pd complex

Pd-catalyzed asymmetric allylic alkylation is recognized as an useful asymmetric carbon-carbon forming process. in which racemic or achiral allylic substrates can be converted to optically active products in the presence of palladium complex of chiral ligand. ': Numerous chiral ligands have been developed in order to achieve high enantioselectivity in the reaction. Phosphinooxazolines such as 1 have received considerable attention as very effective chiral P.N-bidentate ligands. ${ }^{3}$ Recently. we developed new phosphinooxazolidine ligands 2 bearing $s p^{3}$ nitrogen donor for the asymmetric catalysis. ${ }^{+}$The oxazolidines obtainable by simple synthetic route seem to be potential ligands for the asymmetric catalysis. In the context of our research directed towards the development of new oxazolidine ligands. we here present phosphinooxazolidine ligands derived from optically active prolinols, together with their application to the Pd-catalyzed asy mmetric allylation.

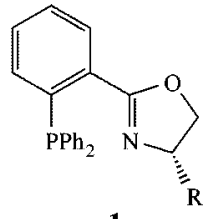

1

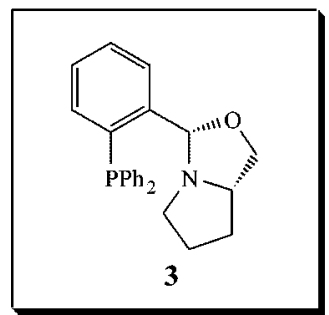

The phosphinooxazolidines 3 and $\mathbf{4}$ were easily prepared through condensation of commercially available 2-(diphenyphosphino)benzaldehyde and I.-prolinol or $\alpha, \alpha$-dipheny l-I.prolinol in refluxing benzene over $12 \mathrm{~h}$. The reaction leads to the formation of new stereocenter $\mathrm{C} 2$ on the oxazolidine ring. Interestingly. 3 and 4 were diastereomerically pure within NMR detection limits. The cis-relative configuration at $\mathrm{C} 2$ was assigned on the basis of the 'H NMR spectral data and the previous stidies. ${ }^{-1}$

The catalytic properties of the palladium complexes formed in situ from the ligands and $\left[\mathrm{Pd}\left(\pi-\mathrm{C}_{3} \mathrm{H}_{5}\right) \mathrm{Cl}\right]_{2}$ were investigated in the asymmetric allylic alkylation of 1.3-
Table 1. Pd-catalyzed asvmmetric ally lic alhvlation of 5 with dimethyl malonate ${ }^{a}$

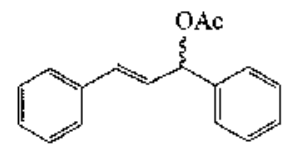

(1) $\mathbf{5}$

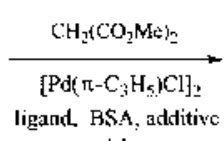

I $\mathrm{h}$

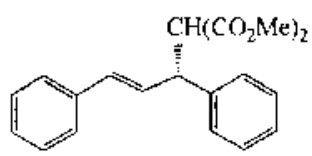

(R)- 6

\begin{tabular}{|c|c|c|c|c|c|c|}
\hline linky & I igand & Solvent & additive & $\begin{array}{c}\text { Tomp. } \\
(" \mathrm{C})\end{array}$ & $\begin{array}{l}\text { Yicld } \\
\left(\begin{array}{l}0 \\
0\end{array}\right)^{\prime \prime}\end{array}$ & ee $\left({ }^{0}{ }_{0}\right)^{c}$ \\
\hline 1 & 3 & THF & $\mathrm{KOAC}$ & 0 & 91 & 81 \\
\hline 2 & 3 & THF & $\mathrm{KOAC}$ & 10 & 97 & 84 \\
\hline 3 & 3 & THF & $\mathrm{KOAC}$ & 22 & 98 & 82 \\
\hline 4 & 3 & $\mathrm{CH}_{2} \mathrm{Cl}_{2}$ & $\mathrm{KOAC}$ & 10 & 98 & 82 \\
\hline 5 & 3 & THF & LiOAc & 10 & 96 & 86 \\
\hline 6 & 3 & THF & $\mathrm{NaOAC}$ & 10 & 95 & 81 \\
\hline $7^{d}$ & 3 & THF & $\mathrm{KOAC}$ & 10 & 92 & 84 \\
\hline 8 & 4 & $\mathrm{THF}$ & LIOAC & 10 & 70 & 86 \\
\hline 9 & 4 & $\mathrm{CH}_{2} \mathrm{Cl}_{2}$ & $\mathrm{KOAC}$ & 10 & 81 & 81 \\
\hline
\end{tabular}

"Reactions werc carried out with $\left.\left[\mathrm{Pd}\left(\pi-\mathrm{C}_{3} \mathrm{H} \mathrm{I}_{5}\right) \mathrm{Cl}\right]_{2}\left(2 \mathrm{~mol}^{\circ}\right)\right)$ ligand (5 molo $\left.{ }^{\circ}\right)$. BSA ( 3 cquir. $)$ additive $\left(4\right.$ molo $\left.^{\circ}\right)$ and dimethyl malonate (.3 equir.) unless noted othenzise. "Measured as "o-comersion into the produce by GC. "Determined by HI'LC with a chiralcel OD-H colum. Absolute configuration was assigned by the sign of the optical rotation and the clution onder from a chiral column. "[Pd( $\left.\left.\pi-\mathrm{C}_{3} \mathrm{H}_{5}\right) \mathrm{Cl}\right]=\left(1 \mathrm{mo}{ }^{0}{ }_{0}\right)$ and ligand $\left(2.5 \mathrm{~mol}^{\circ} \mathrm{o}\right)$ were used.

diphenyl-2-propenyl acetate 5 with dimethyl malonate $\mathrm{N}, \mathrm{O}$ Bis-(trimethylsily) acetanide (BSA) combined with a small amount of KOAc. NaOAc or LiOAc was used as a base. The data obtained are summarized in Table 1. Optimum results were obtained when the reaction was performed at $10^{\circ} \mathrm{C}$ in THF. Use of THF is more desirable than $\mathrm{CH}_{2} \mathrm{Cl}_{2}$ in terms of enantioselectivity: Additive source seems to have a little influence on the ee. BSA-LiOAc gave somewhat better enantioselctivity: Ligand 3 afforded the product $(R)-6$ with $86 \%$ ee under this condition and the alky lation proceeded remarkably fast (entry 5). Reducing the amount of catalyst to $2 \mathrm{~mol} \%$ based on the amount of substrate was still efficient for the reaction (entry 7). Ligand 4 having diphenyl group on oxazolidine ring gave same enantioselectivity as ligand $\mathbf{3}$ (entry 8 and 9). It is interesting that the presence of substituent at $\mathrm{C} 5$ on oxazolidine ring seems to have little influenece on the ee.

The asymmetric induction by ligand 3 can be briefly explained as follows. 


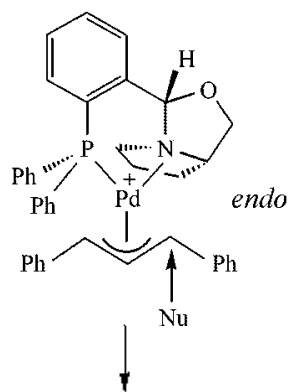

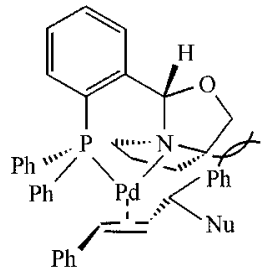
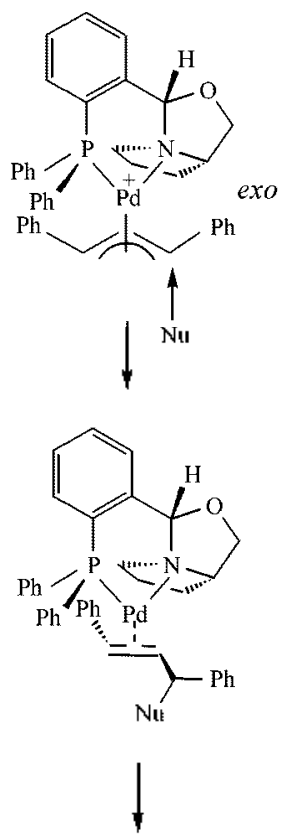

major $(R)$-product

Scheme 1

It has been well known that the nucleophilic attack to $\pi$ allyl complex occurs at the allyl terminal carbon trans to the phosphons which is better $\pi$-acceptor in the P.N-ligand. Presumably the nucleoplilic substitution would proceed preferentially through exo- $\pi$-allylpalladium complex as a major path in which the mucleophilic attack leads to the less sterically-hindered Pd-olefin complex. ${ }^{30,6}$ In the case of endo- $\pi$-allyl complex, severe steric repulsion is generated during the formation of the Pd-olefin complex. Therefore. $(R)$-isomer is formed as the major product. in accordance with the experimental result (Scheme 1). Considering this mechanism, the alkyl substituent at $\mathrm{C}+$ is related to the ee of the reaction. Excellent enantioselectivity has been observed with ligand 2 bearing a bulky group at $C 4 .{ }^{-1}$ In comparison to the ligand 2 . ligand 3 having conformationally rigid py rrolidine ring gave comparable cataly tic activity but lower ee.

In conclusion. we have easily prepared a new kinds of prolinol-based phosphinooxazolidines, which could serve as efficient ligands in the asymmeric Pd-catalyzed allylic alkylation. Further synthesis of chiral oxazolidines and their application are underway in our laboratory.

\section{Experimental Section}

Reactions were carried out under an inert nitrogen atmosphere using dried glassware. All the commercially available reagents were used without further purification. NMR spectra were recorded on a Bnıker AC 250 NMR spectrometer. Elemental analyses were carried out with $\mathrm{CE}$ instrument EA 1110 elemental analyzer. Optical rotation were measured with a Perkin-Elmer $2+1$ polarimeter. The enantiomeric excesses were determined by HPLC analysis (chiralcel OD column: flow rate. $0.5 \mathrm{~mL} / \mathrm{min}$ : detection $25+\mathrm{mm}$ ).

Preparation of pyrrolidinylphosphinooxazolidines. To a solution of 2-(diphenylphosphino)benzaldehy de $(0.25 \mathrm{~g}$. $0.86 \mathrm{munol})$ in degassed benzene $(3 \mathrm{~mL})$ was added 1 prolinol or $\alpha, \alpha$-diphenyl-1.-prolinol $(0.95 \mathrm{mmol})$. The mixture was gradually heated to $80^{\circ} \mathrm{C}$ and allowed to react for $18 \mathrm{~h}$, observing the progress of the reaction by GC. After completion of the reaction, the solvent was evaporated under reduced pressure and the residue was purified by short column chromatography on silica gel pretreated with triethylamine ( $10 \% \mathrm{EtOAc}-5 \% \mathrm{Et}_{3} \mathrm{~N} /$ hexane).

(2S,5S) - 1-Aza-2-(2-diphenylphosphino)phenyl-3-oxabicyclo[3.3.0]octane (3). yield $85 \%:[\alpha]_{0}^{30}=+45.7(\mathrm{c}=1.2$. $\left.\mathrm{CHCl}_{3}\right)$ : MS (El) $m / 2373$ (M'): 'H-NMR: ( $\mathrm{CDCl}_{3} .250$ $\mathrm{MHz}) \delta 7.65(\mathrm{~m} . \mathrm{lH}), 7.65-7.15(\mathrm{~m} .12 \mathrm{H}) .6 .95(\mathrm{~m} . \mathrm{lH})$, $6.03(\mathrm{~d} . J 3.0 \mathrm{~Hz} . \mathrm{lH}), 3.85(\mathrm{t} . J 6.4 \mathrm{~Hz} . \mathrm{lH}), 3.32(\mathrm{~m} .2 \mathrm{H})$, $3.05(\mathrm{~m} . \mathrm{lH}) .2 .72(\mathrm{~m} . \mathrm{lH}), 1.85-1.35(\mathrm{~m} . \mathrm{HH})$ : Anal. Calcd for $\mathrm{C}_{2.1} \mathrm{H}_{2.1} \mathrm{NOP}$ : C. 77.19: H, 6.48: N. 3.75. Found: C. 77.05: H. 6.39: N. 3.67 .

(2S, 5 S ) - 1-Aza-2-(2-diphenylphosphino)phenyl-3-oxa4,4-diphenylbicyclo[3.3.0]octane (4). yield 75\%; $[\alpha]_{D}^{16}=$ $-94.8\left(\mathrm{c}=1.2, \mathrm{CHCl}_{5}\right)$ : MS: $m / \mathrm{z} .525(\mathrm{M})$ : 'H-NMR: $\left(\mathrm{CDCl}_{3}\right.$. $250 \mathrm{MHz}) \delta 7.62(\mathrm{ml}, \mathrm{lH}), 7.11-7.38(\mathrm{~m} .22 \mathrm{H}) .6 .88(\mathrm{~m} . \mathrm{lH})$. $6.36($ d. $J 6.3 \mathrm{~Hz} . \mathrm{HH}) .4 .31$ (t. $J 7.0 \mathrm{~Hz} . \mathrm{lH}) .2 .93(\mathrm{~m} . \mathrm{lH})$ $2.75(\mathrm{ml}, \mathrm{lH}), 1.43-1.70(\mathrm{~m}, 4 \mathrm{H})$; Anal. Caled for $\mathrm{C}_{36} \mathrm{H}_{32} \mathrm{NOP}: \mathrm{C}, 82.26: \mathrm{H}, 6.14 ; \mathrm{N}, 2.66$. Found: C. 81.97; H. $6.09:$ N. 2.51 .

Typical procedure for the Pd-catalyzed asymmetric allylic alylation. In a Schlenk tube a solution of the oxazolidine ligand $(0.025 \mathrm{mmol})$ and allylpalladium chloride dimer $(3.7 \mathrm{mg} .0 .01 \mathrm{mmol})$ in THF $(1.2 \mathrm{~mL})$ was stirred at room temperature for 20 min. To this solution were successively added 1.3-diphenyl-2-propenyl acetate (126 mg. $0.5 \mathrm{mmol}$ ) in THF (1.6 mL). dimethyl malonate (198 mg. $1.5 \mathrm{mmol}$ ), $\mathrm{N}, \mathrm{O}$-bis(trimethylsily l)acetanide $(305 \mathrm{mg}$. $1.5 \mathrm{mmol})$ and metal acetate $(0.05 \mathrm{~mm} / \mathrm{l})$. The mixture was stirred at a given temperature. After the reaction was complete. the reaction mixture was diluted with ether. washed with cold saturated aqueous anmonium chloride solution. The organic layer was dried $\left(\mathrm{MgSO}_{1}\right)$ and concentrated under reduced pressure. The residue was purified by flash chromatography on silica gel ( $15 \%$ EtOAc/hexane). The enantiomeric excess was determined by HPLC analysis (chiralcel OD-H column: flow rate. $0.5 \mathrm{~mL} / \mathrm{min}$; hexane isopropanol $=99: 1, t r=23.4 \mathrm{~min}, t s=25.0 \mathrm{~min}$ ).

Acknowledgment. We thank the Center for Advanced Bioseparation Technology at Inha University for financial support.

\section{References}

1. For recent reviews: (a) Togni. A.: Venanzi. L. M. Lhgew: Chem. lit. F.d Fingl 1994. 33. 497. (b) Trost. B. M.: ran Vranken. D. L. Chem. Ren 1996, 96, 395. (c) Ghosh, A. K.: Mathivanan. P.: Cappiello. I. Tetrohedron: Astmmetry 1998. 9. 1. (d) Itchmelicn. G.: Pfaltz, A. Acc. Chem Res. 2000, 33, 3.36

2. Plallz. A.: Lautens. M. Comprohensive tsmmentic Catallsis. Jacobsen. E. N.: Yamamoto. H.. Eds.: Springer: Heidelbere. 1999. 
3. (a) von Mat1. P': P'laltz. A. Angen: (hem. Int. Ed. Fingl. 1993. 32. 566. (b) Sprine. J.: Helmclien. G.: Tetrohedron Lett. 1993. 3t. 1769. (c) Dawson. G. J.: Frost. C. G.: Williams. J. M. J.: Coote. S. J. Tetwhedron Leff. 1993. 34. 3149. (d) Dawson, G. J.: Williams, J. M. J.: Coote, S. J. Tetrohedrm: Astmmetry 1995 6. 2535. (c) Newmann, I. M.: Williams, J. M. J. Tetrah dron: Astmmetry 1996. 7. 1597. (1) Steinhagen. H.: Reggelin. M.: Helmehen. (i. Angew. (Them. Int Fd Fingl 1997. 36. 2108 (g) Aln. K. H.: Cho. C.-W.: l'ark. J.: Lee. S. Tethohedfon. Asvmmetry 1997. \&. 1179. (h) Pretot. R.: Pfaltz. A. Angew. Chem. Int. Ed. Engl. 1998. 37. 323. (i) Kudis, S.: J Helmehen, G. Angen: Chem. Int. Ed. Engl 1998, 37. 3047. (j) Imai. Y: 7.hang. W: Kida, T.: Nakatsuji, Y.: Ikeda, I. Tetrahedhon Lett. 1998. 39. 4343. (h) Fukuda. T.: Takehara. A.:
Iwao. M. Tetrahedron, istmmetry 2001. 12. 2793.

4. Jin. M.-I.: Ju1n. J.-A.: Kim. S.-H. Tetrahedron Lett 1999. 40. 5197.

5. The formation of cis-isomer of oxazolidine is faxored under kinetic and thermodynamic conditions. (a) Beckett. $\Lambda$. II.: Jones, G. R. Thtrahedrm 1977, 34. 3313. (b) Mangener, P.: Alexakis, A.; Nomant. .T. F. Tetwohedron 1984. 40 . 1803. (c) Bemardi. A.: Cardani. S.: Pilati. T.: Poli. G.: Sodastico. C.: Villa. R. J. Org. (hem 1988. 53. 1600)

6. Dierkes. P.: Ramdechul. S.: Barlow, I.: Cian, A. D.: Fischer, I.: Kamer. P. C. J: ran I ceuven. P. W. N. M.: Osbom. J. A. Angew. Chem. fil. Edt. Engt. 1998. 37. 3116. 